\title{
A Possible Chelonian Egg from the Brazilian Late Cretaceous
}

\author{
SERGIO ALEX AZEVEDO ${ }^{1}$, VALÉRIA GALLO ${ }^{2}$ and JORGE FERIGOLO ${ }^{3}$ \\ ${ }^{1}$ Departamento de Geologia e Paleontologia, Museu Nacional, \\ Universidade Federal do Rio de Janeiro - 20940-040 Rio de Janeiro, RJ, Brasil \\ ${ }^{2}$ Departamento de Biologia Animal e Vegetal, Instituto de Biologia, \\ Universidade do Estado do Rio de Janeiro - 20559-900 Rio de Janeiro, RJ, Brasil \\ ${ }^{3}$ Fundação Zoobotânica, P.O. Box 1188 - 90690-000 Porto Alegre, RS, Brasil
}

Manuscript received on November 24, 1998; accepted for publication on November 9, 1999; presented by CÂNDIDo Simões Ferreira

\begin{abstract}
This paper describes a possible fossil egg proceeding from the Bauru Group, Late Cretaceous of Paraná Basin, Brazil. External morphology, dimensions, texture and shell ornamentation examined under electron microscopy show close resemblance to the Recent podocnemidid chelonian eggs. Association with bony material in the outcrop suggests that it is related to a species of Podocnemis.

Computerized tomography reveals a high density outer region corresponding to the shell component layers, and successive layers with decreasing density towards the nucleus. An area of high density in the central region may represent remains of an embryo.
\end{abstract}

key words: Fossil egg, chelonian, Late Cretaceous, Bauru Group.

\section{INTRODUCTION}

This study analyses a reptilian fossil egg from sediments of the Bauru Group, Late Cretaceous of Paraná Basin, Brazil. References to the occurrence of complete fossilized eggs or eggshell fragments assigned to reptiles are relatively common in paleontological literature worldwide. There are wellknown deposits in Utah and Montana, USA (Jepsen 1931, Jensen, 1966 1970, Horner \& Makela 1979, Horner 1982 1984, Hirsch \& Quinn 1990, Maxwell $\&$ Horner 1994) and in the Gobi Desert in Mongolia (Andrews 1932, Sochava 1969, 1971, Kurzanov \& Mikhailov 1989, Mikhailov 1995), as well as in a wide variety of geological formations from various continents (e.g., Matheron 1869, Gervais 1877,

Correspondence to: Sergio Alex Azevedo

E-mail: sazevedo@acd.ufrj.br
Chow 1951 1954, Young 1954 1959, Hirsch 1989 , Kohring 1990 1991). Most of these fossils are assigned to dinosaurs. A review of this subject was presented by Hirsch \& Packard (1987).

In Brazil, the paleontological findings from the Late Cretaceous Bauru Group in Peirópolis region, Municipality of Uberaba (MG), are of great importance. Among others, there is a natural egg cast spheric in shape (DGM 348-R), without the outer shell, measuring about 15.0 centimeters and has been assigned with "relative certainty" (Price 1951, p. 5) to the Titanosauridae. Three oblong eggs from the Peirópolis region (DGM 1450-R, DGM 1451$\mathrm{R}$ and DGM 1452-R), with different states of outer shell preservation and measuring 5.8 to 11.0 centimeters in diameter, were assigned to the Ornithischia, possibly Ceratopsia (Campos \& Bertini 1985). In addition to the Peirópolis occurrences, Vi- 


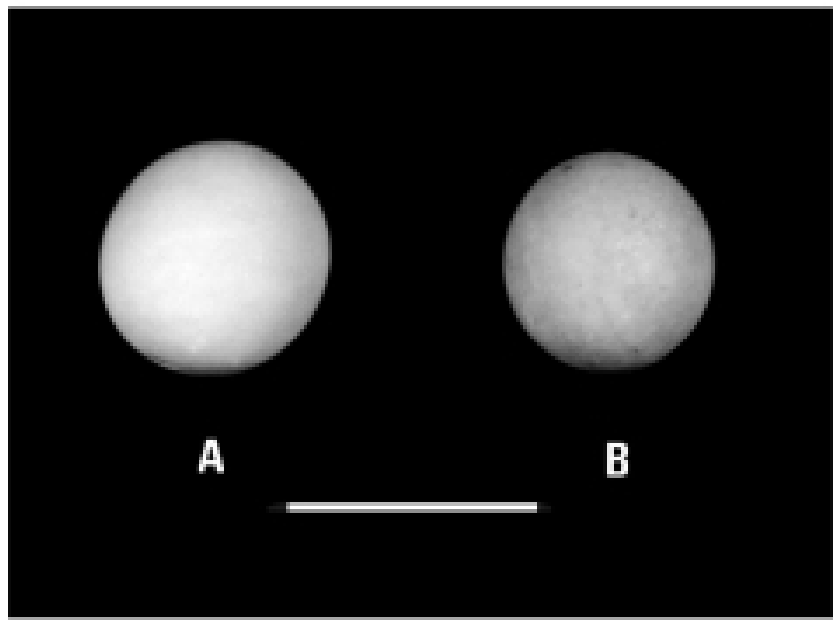

Fig. $1-$ Chelonian eggs $($ Scale bar $=5 \mathrm{~cm})$. A: Recent egg (Podocnemis expansa); B: Fossil egg (MN 4315-V).

calvi et al. (1993) reported the finding of reptilian eggshell fragments in the Itapecuru Formation (Late Cretaceous of Parnaíba Basin). Those authors did not present a formal taxonomic classification, but compared their material to ornithoid dinosaur eggs. Outside Brazil, the material described by Mones (1979) and referred to the Asencio Formation (Late Cretaceous of Uruguay), as well as egg remains described by Bonaparte \& Vince (1979) from the El Tranquilo Formation (Late Triassic of Argentina), and some dinosaur eggs still under analysis recently reported from Argentinian southern, can provide subsides to the study of Brazilian material.

\section{MATERIAL}

The fossil egg studied is housed at the Paleovertebrate Collection of the Museu Nacional/Universidade Federal do Rio de Janeiro (MN 4315-V). It was collected in 1986 by Professor Fausto Luiz de Souza Cunha in the Cretaceous mudstones of Adamantina Formation, Bauru Group at the locality of Álvares Machado (22 $\left.4^{\prime} 22^{\prime \prime} \mathrm{S} 51^{\circ} 29^{\prime} 36^{\prime \prime} \mathrm{W}\right)$, northwest of Presidente Prudente City, São Paulo State, Brazil.
The fossil egg was compared to Recent egg material and to fossil bones assigned to reptiles stratigraphically associated. The chemical composition and the egg surface were studied under Scanning Electron Microscope. The internal structure was studied through radiological techniques, including computerized tomography, at the Radiology Service of São Lucas Hospital (PUC/RS) and high resolution tomography at the Radiodiagnostic Service of the University Hospital (Universidade Federal do Rio de Janeiro).

\section{RESULTS AND DISCUSSION}

The egg (Fig. 1), with excellent preservation, subspherical format, measuring about 4.30 centimeters, was found associated to remains of titanosaurid dinosaurs, crocodilians and chelonians described by Souza Cunha et al. (1987) and was preliminary identified as a "dinosaur egg (?)".

In view of the almost perfectly spherical shape and reduced size it is unlikely that the egg belongs to dinosaurs. The specimen is tentatively assigned to a chelonian egg.

Chemical analysis of the fragments of the outer portion of the specimen indicated the predominance of calcium carbonate (Fig. 2). Under binocular mi- 


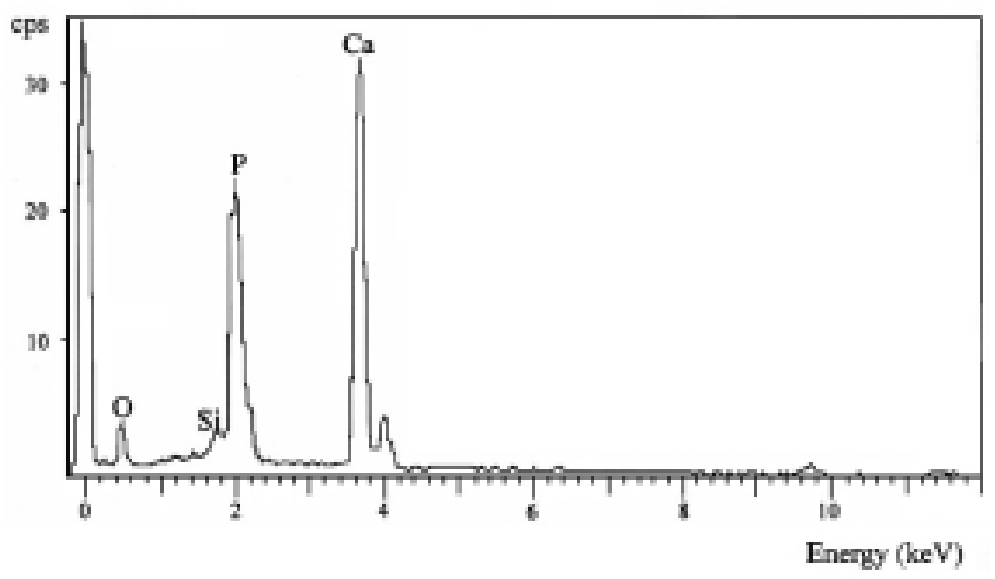

Fig. 2 - X-ray analysis of the outer surface of the eggshell.

croscope the outer surface of the egg revealed little rugosity as found in eggshells of Recent podocnemidids (Podocnemis expansa) utilized for comparison.

Under SEM analysis of ultra-structure revealed a great similarity between morphology and arrangement of elongated crystals of calcium carbonate in egg's shell, and the Recent material (Fig. 3).

To detect density changes, in order to characterize the internal structure, the specimen was examined under high definition computerized tomography, a technique previously utilized in similar situations (Conroy \& Vannier 1984 1987, Haubitz et al. 1988, McGowan 1989a 1989b) which showed extremely efficient for the desired objective.

The tomographic sections revealed an internal structure characterized by the presence of a particularly dense outer region, corresponding to the shell layers. Toward the nucleus, the specimen shows reduced values of mass density (Fig. 4). It was also possible to identify in the central portion a region of greater density, and inside this region there were individualized points of even greater density.

It is possible to hypothesize that the dense central region represents an embryonic remain, and the points of greater density represent the centers of ossification of bones in formation. This observation is extremely rare in fossilized eggs (Sochava 1972, Elzanowsky 1981, Horner 1982).
One of the tomographic sections (Fig. 5) showed a shape similar to an embryo. Such resemblance becomes more evident in comparison with embryonic material of Pseudemys virginica presented by Grassé (1970, p. 931).

As the computerized tomography allows the quantification of density values with high precision, it is worth mentioning that the density values in the ossifications of the supposed embryo (4212) are numerically very similar to the values taken as reference for fossilized bones of associated chelonian bones (4228). Notice that the range of values of density utilized in the equipment was of -11000 to +11000 , relative to the density taken as reference (water $=1$ ).

\section{CONCLUSIONS}

(1) The morphological characteristics and microand ultra-structure of shell suggest identification of the fossil as a chelonian egg.

(2) On account of the paleofaunistic association in the outcrop where the egg came from, and through the comparison with Recent remains, we tentatively refer the egg to the genus Podocnemis.

(3) Analysis of high definition computerized tomography made it possible to identify a probable embryonic remain. 


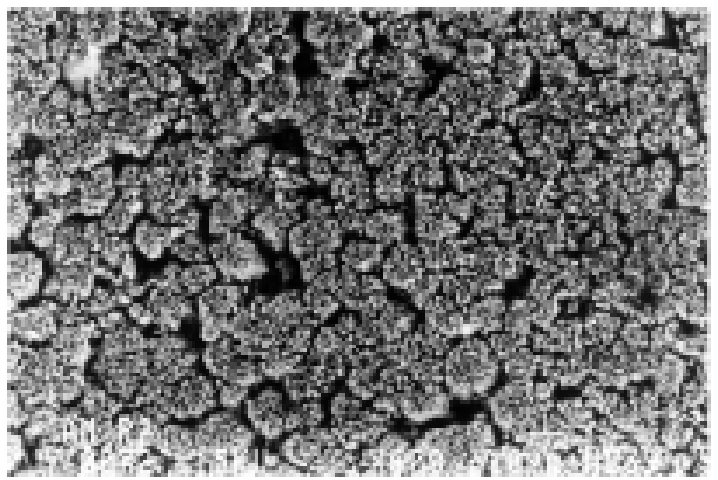

\section{A}

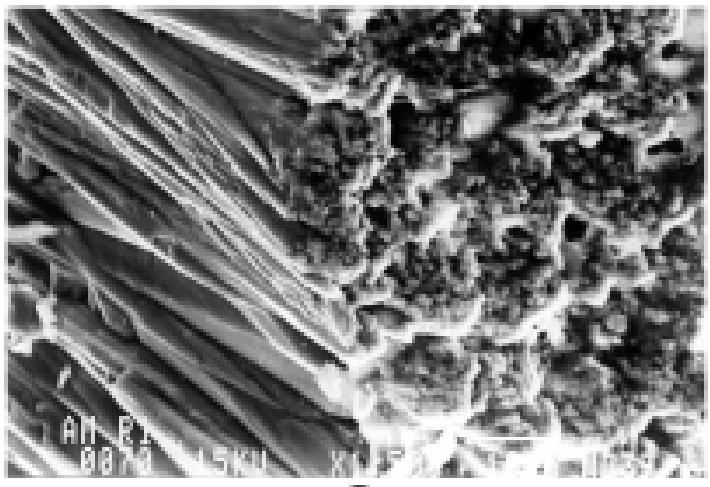

C

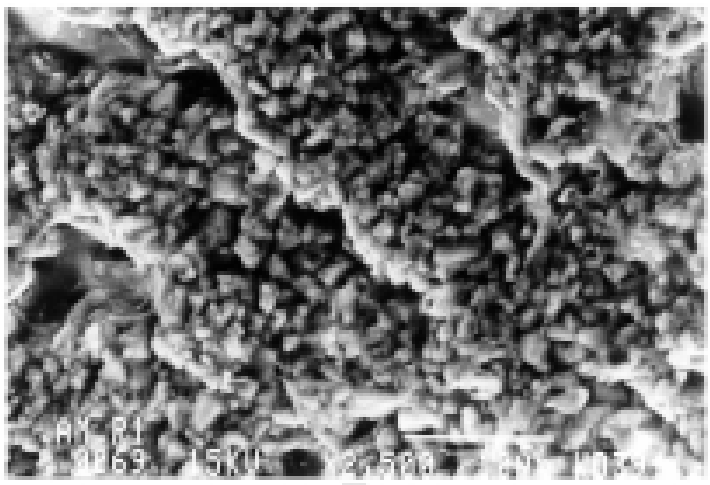

$\mathrm{E}$

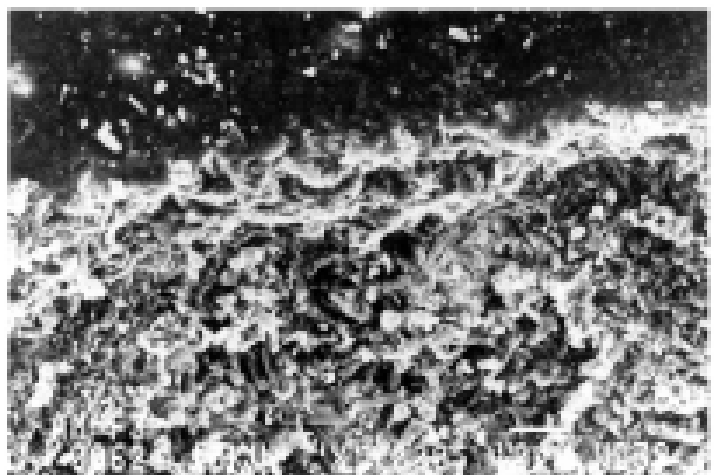

B

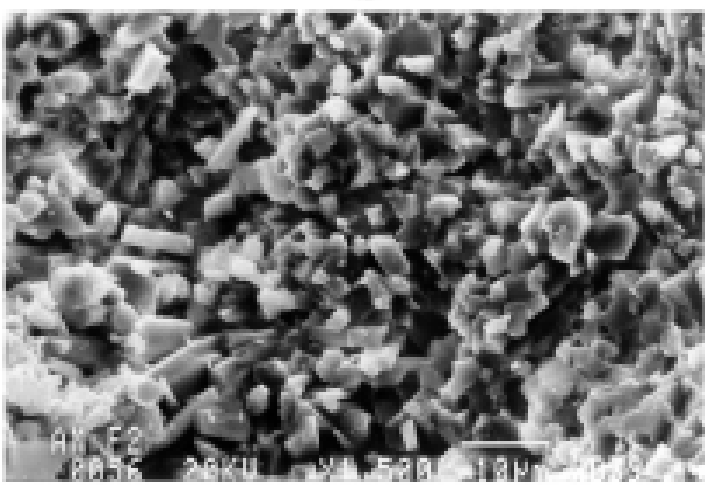

$\mathrm{D}$

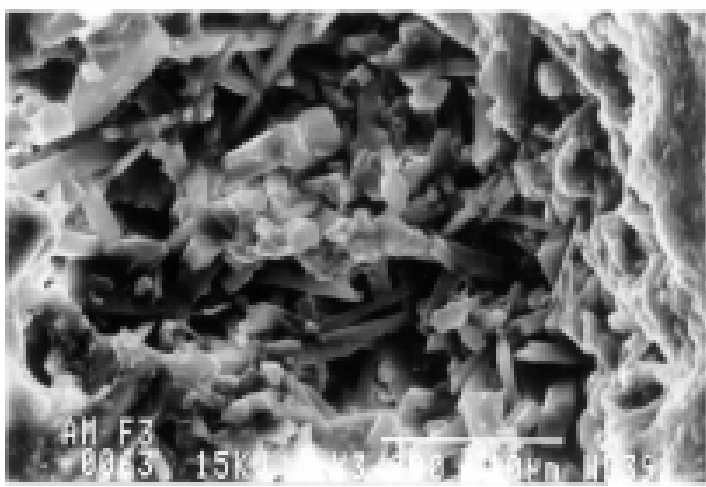

$\mathrm{F}$

Fig. 3 - SEM micrographs of shell ultra-structure. A: Recent chelonian (Podocnemis expansa $-\times 600$ ); B: MN 4315-V ( $\times 1000)$; C: Recent chelonian (Podocnemis expansa $-\times 1500)$; D: MN 4315-V (× 1500); E: Recent chelonian (Podocnemis expansa $-\times 2500)$; F: MN 4315-V $(\times 3000)$. 


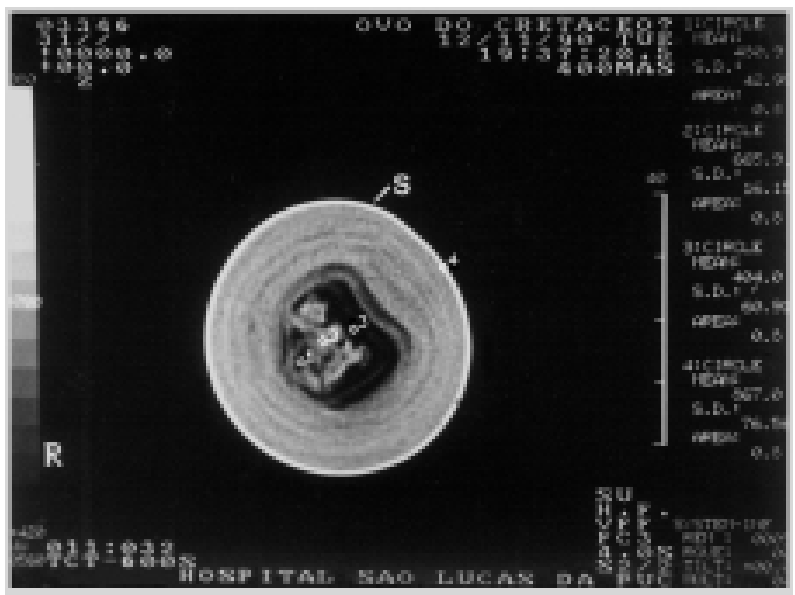

Fig. 4 - Computerized tomography of specimen MN 4315-V. s: shell; 1 to 4 : points of different density.
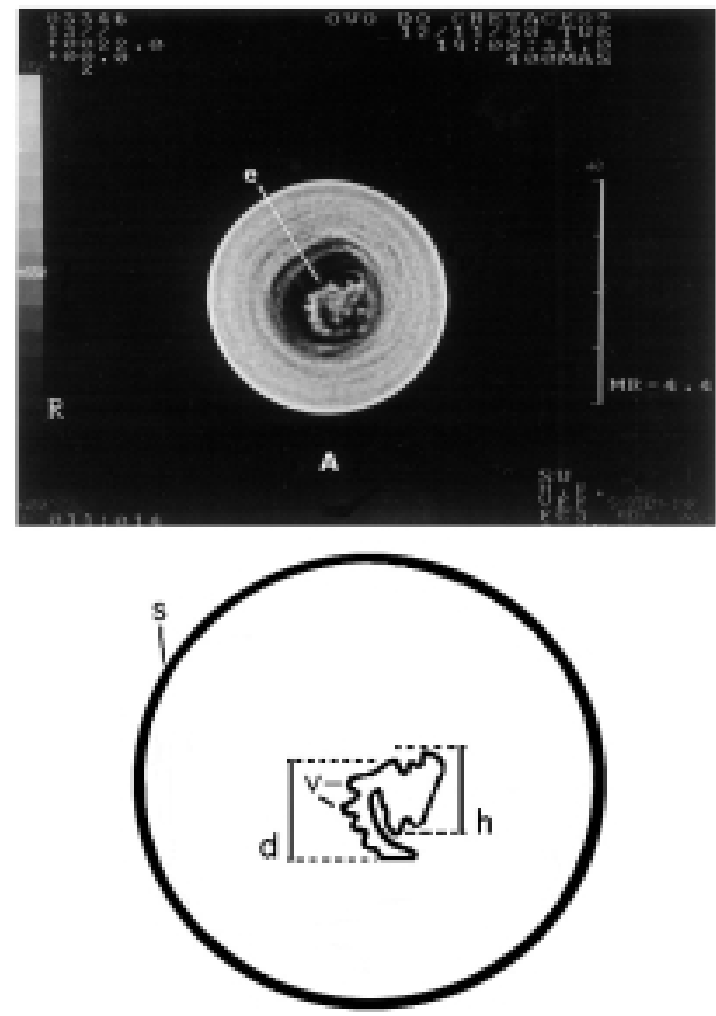

B

Fig. 5 - MN 4315-V. A: Computerized tomography of specimen; e: embryonic body; B: Morphological analysis of computerized tomography; h: head; d: dorsum; v: vertebrae.
(4) This fossil egg is the first chelonian egg described from the Late Cretaceous of Brazil.

\section{ACKNOWLEDGEMENTS}

The authors wish to acknowledge Dr. Abércio Arantes Pereira and the Technician Jorge Pires da Silva (Radiodiagnostic Service of University Hospital/UFRJ), as well as the São Lucas Hospital of PUC/RS for their help on the execution of computerized tomographies; to the Research Center Leopoldo A. Miguez de Mello (Cenpes/Petrobrás) for the use of the SEM and photography of specimen; to Dr. Celeste Carvalho Siqueira Elias (Faculdade de Medicina/UFRJ); to Dr. Sérgio Fernandes Villaça (COPPE/UFRJ); to Dr. Paulo Andreas Buckup (Museu Nacional/UFRJ); and to Hugo Ricardo Secioso Santos (DBAV/UERJ) for their collaboration in this study.

\section{REFERENCES}

ANDRews RC. 1932. The New Conquest of Central Asia. Natural History of Central Asia, The American Museum of Natural History, Vol. I, New York, 678p.

Bonaparte JF \& Vince M. 1979. El hallazgo del primer nido de dinosaurios triasicos, (Saurischia, Prosauropoda), Triasico Superior de Patagonia, Ar- 
gentina. Ameghiniana 15(1-2): 173-182.

Campos DA \& Bertini RJ. 1985. Ovos de dinossauro da Formação Uberaba, Cretáceo Superior do Estado de Minas Gerais. In: IX Congresso Brasileiro de Paleontologia, Fortaleza. Resumos... Fortaleza, SBP, p. 19.

CHow MC. 1951. Notes on the Late Cretaceous dinosaurian remains and the fossil eggs from Laiyang, Shantung. Bull Geol Soc China 31: 89-96.

CHow MC. 1954. Additional notes on the microstructure of the supposed dinosaurian eggshells from Laiyang, Shantung. Acta Scientia Sinica 3(4): 523-525.

Conroy GC \& Vannier MW. 1984. Noninvasive threedimensional computer imaging of matrix-filled fossil skulls by high-resolution computed tomography. Science 226: 456-458.

Conroy GC \& Vannier MW. 1987. Dental development of the Taung skull from computerized tomography. Nature 329: 625-627.

Elzanowski A. 1981. Embryonic bird skeletons from the Late Cretaceous of Mongolia. Paleontologica Polonica 42: 147-179.

Gervais MP. 1877. Structure des coquilles calcaries des oeufs et caracteres que l'on peut en tirer. J Zoologie tomo VI: 88-96.

Grassé PP. 1970. Traité de Zoologie. Paris, Masson et Cie. Editeurs, Tome XVI, fasc. III. p. 682-1428.

Haubitz B, Prokop M, Döhring W, Ostrom JH \& Wellnhofer P. 1988. Computed tomography of Archaeopteryx. Paleobiology 14(2): 206-213.

HiRsCH KF. 1989. Interpretation of Cretaceous and Precretaceous eggs and shells fragments. In: Gillette DD \& Lockley MG eds. Dinosaurs Tracks and Traces. New York, Cambridge University Press, cap. 10, p. 81-97.

HiRsch KF \& PACKARD MJ. 1987. Review of fossil eggs and their shell structure. Scan Microsc 1(1): 383-400.

HiRsch KF \& QuinN B. 1990. Eggs and eggshell fragments from the Upper Cretaceous Two Medicine For- mation of Montana. J Vertebrate Paleontol 10(4): 491-511.

HORNER JR. 1982. Evidence of colonial nesting and "site fidelity" among ornithischian dinosaurs. Nature 297: 675-676.

HoRner JR. 1984. The nesting behavior of dinosaurs. Scientific American 250(4): 130-137.

Horner JR \& Makela R. 1979. Nest of juveniles provides evidence of family structure among dinosaurs. Nature 282: 296-298.

Jensen JA. 1966. Dinosaur eggs from the Upper Cretaceous North Horn Formation of Central Utah. Brigham Young University Geol Stud 13: 55-67.

Jensen JA. 1970. Fossil eggs in the Lower Cretaceous of Utah. Brigham Young University Geol Stud 17: 51-65.

JEPSEN GL. 1931. Dinosaur eggshell fragments from Montana. Science 73: 12-13.

KoHRING R. 1990. Upper Jurassic chelonian eggshell fragments from the Guimarota Mine (Central Portugal). J Vertebrate Paleontol 10(1): 128-130.

KoHRING R. 1991. Lizard eggshells from the Lower Cretaceous of Cuenca Province, Spain. Paleontology 34 Part I: 237-240.

Kurzanov SM \& Mikhailov KE. 1989. Dinosaur eggshells from the Lower Cretaceous of Mongolia. In: Gillette DD \& Lockley MG eds. Dinosaurs Tracks and Traces. New York, Cambridge University Press, cap. 12, p. 109-113.

Matheron MP. 1869. Notice sur les Reptiles fossiles des dépots fluvio-lacustres Crétacés du bassin a lignite de Fuveau. Mémoire de l'Academie Imperiale des Sciences, Belles-Lettres et Arts de Marseille, 1869: 345-379.

Maxwell WD \& Horner JR. 1994. Neonate dinosaurian remains and dinosaurian eggshell from the Cloverly Formation, Montana. J Vertebrate Paleontol 14(1): 143-146.

McGowan C. 1989a. The ichthyosaurian tailbend: a verification problem facilited by computed tomography. Paleobiology 15(4): 429-436. 
McGowan C. 1989b. Computed tomography reveals further details of Excalibosaurus, a putative ancestor for the swordfish-like ichthyosaur Eurhinosaurus. $J$ Vertebrate Paleontol 9: 269-281.

Mikhailov KE. 1995. Systematic, faunistic and stratigraphic diversity of Cretaceous eggs in Mongolia: comparison with China. In: Sixth Symposium on Mesozoic Terrestrial Ecosystems and Biota, Beijing. Short Papers... Beijing, p. 165-168.

Mones A. 1979. Nuevos elementos de la paleoherpetofauna del Uruguay (Crocodilia y Dinosauria). In: II Congreso Argentino de Paleontologia y Bioestratigrafia y I Congreso Latinoamericano de Paleontologia, Buenos Aires. Actas... Buenos Aires, v. 1, p. 265-277.

Price LI. 1951. Um ovo de dinossaurio na Formação Bauru, do Cretácico do Estado de Minas Gerais. Notas Preliminares e Estudos DNPM/DGM 53: 1-7.
Sochava AV. 1969. Dinosaur eggs from the Upper Cretaceous of the Gobi Desert. Paleontological Journal 1969(4): 517-527.

Sochava AV. 1971. Two types of eggshell in Senonian dinosaurs. Paleontol J 1971(3): 353-361.

SochaVA AV. 1972. The skeleton of an embryo in a dinosaur egg. Paleontol J 1972(4): 527-531.

Souza Cunha FL, Rego DD \& Capilla R. 1987. Nova ocorrência de répteis cretácicos no "Sitio Myzobuchi” da Formação Bauru, em Álvares Machado, SP. In: X Congresso Brasileiro de Paleontologia, 10, Rio de Janeiro. Anais... Rio de Janeiro, SBP, v. 1, p. 143-154.

Vicalvi MA, Ferreira CS, Carvalho IS \& Anjos SM. 1993. Fragmentos de ovos de dinossauros na Formação Itapecuru, Maranhão: Uma discussão. $A n$ Acad Bras Ci 65(2): 18.

Young C-C. 1954. Fossil reptilian eggs from Laiyang, Shantung, China. Scientia Sinica 3: 505-522.

Young C-C. 1959. New fossil eggs from Laiyang, Shantung. Vertebrata PalAsiatica 3: 34-35. 